\title{
A Case of Perianal Fistula Presented with Deep Soft Tissue Infection on the Lateral Side of the Thigh
}

\section{Uyluğun Lateral Tarafında Derin Yumuşak Doku Enfeksiyonu ile Başvuran Bir Perianal Fistül Olgusu}

\author{
(1) Süleyman Çağlar Ertekin1, (1) Wafi Attaallah1, (1) Rabia Ergelen² \\ ${ }^{1}$ Marmara University Faculty of Medicine, Department of General Surgery, İstanbul, Turkey \\ 2Marmara University Faculty of Medicine, Department of Radiology, İstanbul, Turkey
}

\section{\|I\|\|\|II ABSTRACT}

A typical fistula usually consists of a tract with a primary (internal) opening in the anus or rectum and a secondary (external) opening on the perirectal skin. There have been very few case reports where a fistula in ano has traversed an unusual course and caused a diagnostic dilemma. In this report we presented a case of perianal fistula presented with osteomyelitis on the lateral side of right. The patient was previously admitted to another center where she was diagnosed with deep soft tissue infection on thigh associated with osteomyelitis and underwent three consecutive operations within 6 months for drainage and debridement. However healing was not achieved. A pelvic magnetic resonance imaging showed suprasphincteric anal fistula that extended to the lateral side of the right thigh. Crohn's disease was excluded. The patient was referred to our center and fistula tract was irrigated with a $1 \%$ silver nitrate solution. After long follow up, the patient showed complete cessation of the discharge with complete healing of external orifices of the fistula.

This report described an unusual perianal fistula extending to the thigh. Previously this case was diagnosed as osteomyelitis. It is important to consider perianal fistulas as a differential diagnosis for this type of wounds and the application of silver nitrate solution often produces a favorable outcome in such cases.

Keywords: Perianal fistula, osteomyelitis, thigh

\section{|HIIIII| ÖZ}

Tipik bir anal fistül genellikle anüste veya rektumda iç (primer) orifise ve perirektal deride dış (sekonder) orifise sahip bir trakttan oluşur. Literatürde atipik yerleşimli fistüller ile ilgili az sayıda olgular bildirilmiştir. Bu yazıda, sağ uyluğun lateral tarafında osteomiyelit ile başvuran bir perianal fistül olgusu sunulmaktadır. Hasta daha önce başka bir merkeze başvurmuş ve sağ uyluğun lateral tarafında osteomiyelite kadar ilerleyen derin yumuşak doku enfeksiyonu tanısı almış. Drenaj ve debridmanı için 6 ay içinde art arda üç operasyon geçirmiştir. Çekilen pelvik manyetik rezonans görüntülemede sağ uyluğun lateral tarafına uzanan suprasfinkterik anal fistül görüldü. Crohn hastalığı dışlandı. Hasta merkezimize sevk edildi. Fistül traktı \% 1 gümüş nitrat çözeltisi ile irrige edildi. Uzun takipten sonra hastanın akıntısı tamamen kesildi ve dış ağızlar tamamen kapandı.

Bu yazıda, uylukta osteomiyelit tanısı ile tedavi edilen hastalarda perianal fistüllerin ayırıcı tanıda değerlendirilmesi uygun olacaktır. Bu tarz atipik ve komplike fistüllerde cerrahiye alternatif olarak gümüş nitrat solüsyonu ile irrigasyon uygun bir tedavi yöntemi olarak önerilebilir.

Anahtar Kelimeler: Perianal fistül, osteomiyelit, uyluk

\section{Introduction}

Anorectal fistula is a chronic manifestation of the acute perirectal process that forms an anal abscess. When the abscess ruptures or is drained, an epithelialized track can form, which connects the abscess in the anus (or rectum) with the perirectal skin. ${ }^{1}$

A patient with an anal fistula may complain of recurrent malodorous perianal discharge, pruritus, recurrent abscesses, fever, or perianal pain due to an occluded tract.

Address for Correspondence/Yazışma Adresi: Wafi Attaallah MD, 
A fistula-in-ano represents the chronic phase of ongoing peri-anal infection. It is a granulating tract between the anorectum and the perianal region (or perineum). A typical fistula usually consists of a tract with a primary (internal) opening in the anus or rectum and a secondary (external) opening on the perirectal skin. ${ }^{2}$ There have been very few case reports where a fistula in ano has traversed an unusual course and caused a diagnostic dilemma. Perianal fistula extended to the thigh has not been described in the literature before. Here we reported a case of perianal fistula that presented with deep soft tissue infection on the lateral side of the thigh.

\section{Case Report}

A 35 year old woman was admitted to Marmara University Faculty of Medicine Department of General Surgery with complaints of cramping right leg pain radiating to the gluteal region. The patient was previously admitted to another center and was diagnosed with deep soft tissue infection on the lateral side of the right thigh associated with osteomyelitis and underwent three consecutive operations within 6 months for drainage and debridement. However healing was not achieved and discharge from the wound continued with sustained pain. In order to better understand the underlying problem, further evaluations were performed. Pelvic magnetic resonance imaging (MRI) results showed a suprasphincteric anal fistula that extended to the lateral side of the right thigh. At that point, the patient was referred to our hospital. Physical examination showed a purulent discharge from 2 different orifices located along a $30 \mathrm{~cm}$ scar from incisions during earlier treatment on lateral side of the right thigh and at $40 \mathrm{~cm}$ away from the anus (Figure 1). On digital rectal examination no internal orifice was palpated. Her blood test only showed mild neutrophilia. Colonoscopy was performed and Crohn's disease was excluded.

Abdominal and perianal MRI was performed to confirm the diagnosis and determine the level of the fistula. MRI results showed a suprasphincteric fistula located at 11 o'clock on the lithotomy position. The fistula extended through the right obturatorius internus muscle to the gluteal muscles (Figure 2, 3A, 3B).

After informed consent was obtained, treatment with silver nitrate irrigation was performed.

Thereafter, the fistula tract was irrigated with a $1 \%$ silver nitrate solution in the outpatient clinic. The patient was positioned in the left lateral decubitus position. An olive tipped malleable metal probe was inserted through the external orifice to check the patency and determine the main tract of the fistula. An 8fr feeding catheter was inserted through the external orifice into the fistula tract. At the same time, a digital rectal exam was performed to ensure that the catheter did not protrude into the anal canal. Once the catheter was properly positioned, $5 \mathrm{~mL}$ of $1 \%$ silver nitrate solution (MERCK, Germany) was delivered into the fistula tract while withdrawing the catheter from the tract when the patient felt the fluid inside the anal canal. The length of the fistula tract was $30 \mathrm{~cm}$ measured by the catheter inserted into the tract. Irrigation was repeated every 4 weeks. A total of 10 irrigations with $1 \%$ silver nitrate solution was done. After a total 24 months of follow up the patient showed complete cessation of the discharge with complete healing of external orifices of the fistula without any complication (Figure 4).
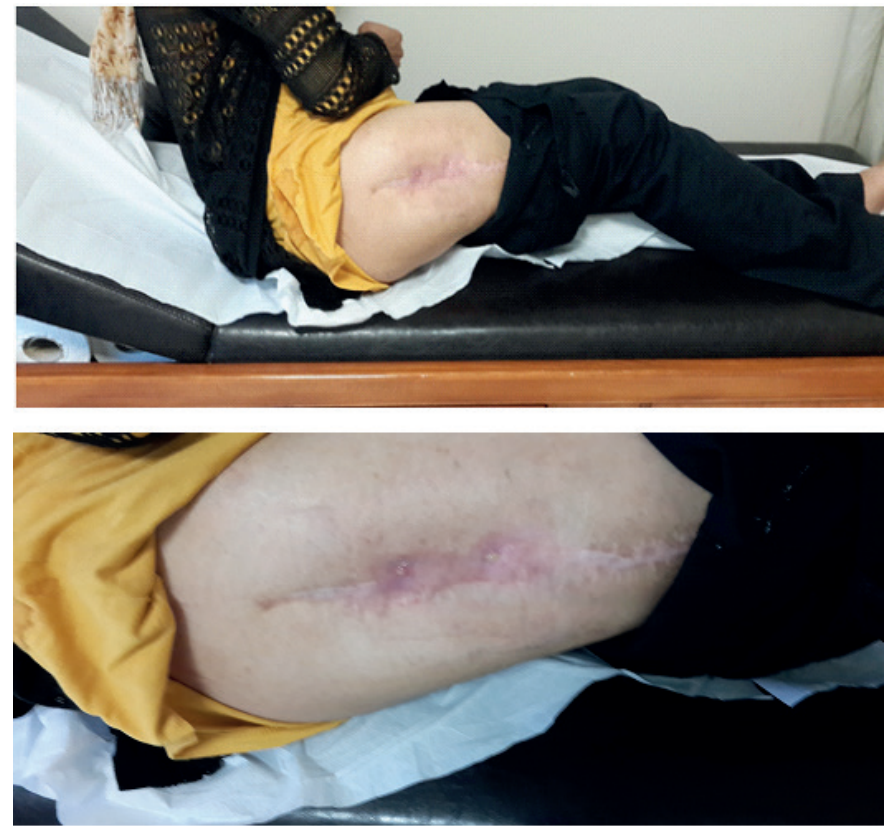

Figure 1. Two different orifices located along a $30 \mathrm{~cm}$ scar from incisions during earlier treatment on lateral side of the right thigh

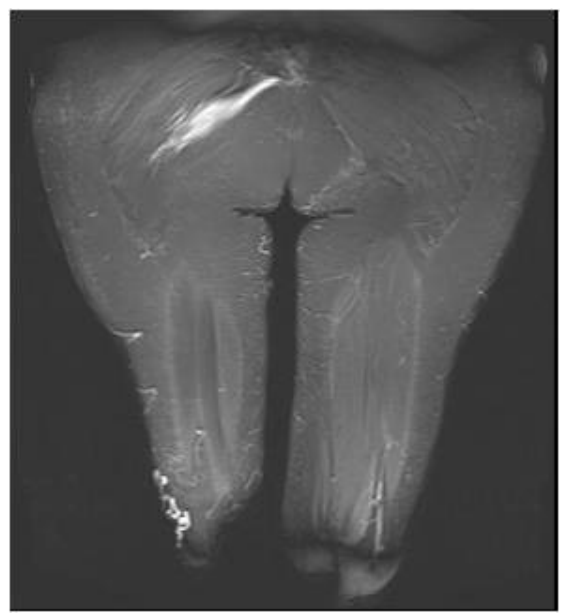

Figure 2. Coronal fat-sat T2-weighted image shows fistul tract orginating from perianal region 


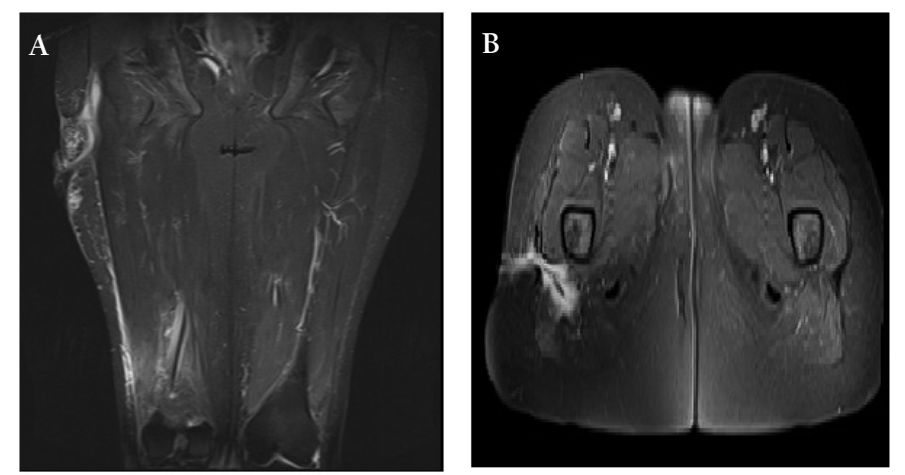

Figure 3. Axial fat-sat T2 weighted contrast enhanced T1-weighted A) Coronal and B) Axial images demonstrate active fistul tract extended lateraly to the femur with secondary (external) opening on the thigh skin

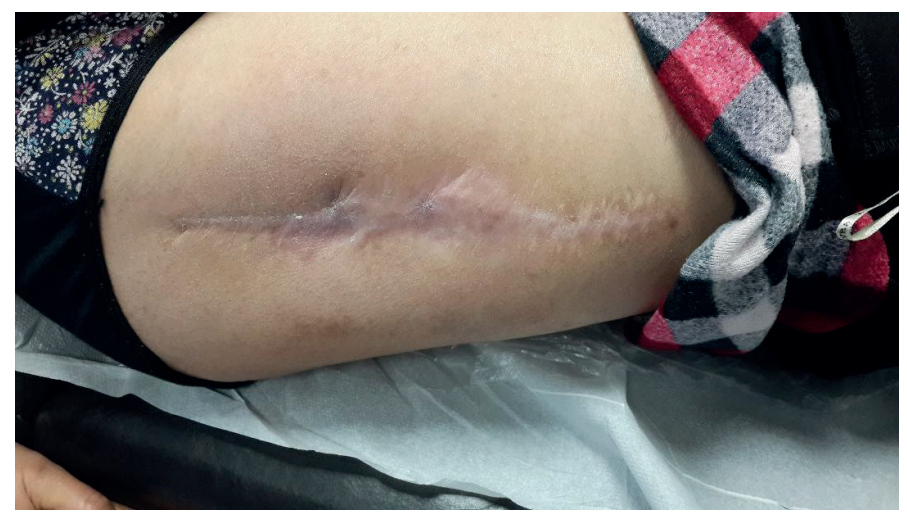

Figure 4. Complete healing of external orifices of the fitula with complete cessation of the discharge after irrigations of the fistula tract with silver nitrate solution

\section{Discussion}

The classification system developed by Parks, Gordon, and Hardcastle (generally known as the Parks classification) is the most commonly used system for fistula-in-ano. This system defines four types of fistula-in-ano that result from cryptoglandular infections: intersphincteric, transsphincteric, suprasphincteric, and extrasphincteric. ${ }^{3}$

Intersphincteric fistulas-in-ano account for $70 \%$ of all anal fistulas, and extrasphincteric fistulas-in-ano account for $1 \%$ of all anal fistulas while the majority of fistulas are cryptoglandular in origin, trauma, Crohn's disease, malignancy, radiation, or unusual infections (tuberculosis, actinomycosis, and chlamydia) may also produce fistulas. A complex, recurrent, or nonhealing fistula should raise the suspicion of one of these diagnoses. ${ }^{4}$ In this study we presented a case of complex perianal fistula unrelated to the above mentioned conditions.

In this study we have presented a case of perianal fistula with unusual localization and clinical manifestation. The patient had 3 operations within 6 months because of osteomyelitis and recurrent sepsis before. She was diagnosed with suprasphincteric perianal fistula extending to the lateral side of right thigh. There have been very few case reports where a fistula-in-ano has traversed an unusual course and caused a diagnostic dilemma. One known report includes a fistula in ano involving and causing septic arthritis of the hip. ${ }^{5}$ Another case reported a patient who presented with the complaints of a painless lump in the right buttock region and was finally diagnosed as a complex fistula-in-ano presenting as a soft tissue tumor. ${ }^{2}$

Fistulotomy is common treatment modality for anal fistulas. However, fistulotomy is associated with complications such as permanent incontinence, which reduces quality of life. Alternative procedures used to treat complex fistulas include setons, advancement flaps, advancement flap with fibrin sealant, the modified Hanley procedure, and ligation of the intersphincteric fistula tract (LIFT) procedures. ${ }^{6,7}$ Regardless of the available procedure techniques, no optimal treatment has been defined for anal fistula. Although various treatment modalities have been described, no treatment for fistulain-ano described so far can be considered optimal. ${ }^{8}$ The need of treatment for anal fistula is because of spontaneous healing is very rarely can occur. One possible explanation for the persistence of anal fistula is the epithelialization of the fistula tract, which prevents the fistula from closing. ${ }^{9}$ We reasoned, therefore, that ablation of this epithelial tissue using silver nitrate solution (a corrosive chemical agent) would damage the tract and lead to healing with fibrosis and eventually closure of the tract without surgical intervention. In a previous pilot (preliminary) study, we showed that the application of silver nitrate solution into the fistula tract often produces a favorable outcome in the treatment of anal fistula. ${ }^{10}$

In this case irrigation of the fistula tract with $1 \%$ silver nitrate solution was done. After about 2 year of follow up complete cessation of the discharge with complete healing of external orifices was observed.

\section{Conclusion}

This report described unusual perianal fistula extending to the thigh which was previously diagnosed as osteomyelitis. It is important to keep in mind the perianal fistulas as a differential diagnosis for this type of wounds and the application of silver nitrate solution often produces a favorable outcome in such cases.

\section{Ethics}

Informed Consent: It was obtained.

Peer-review: Externally peer-reviewed.

Conflict of Interest: No conflict of interest was declared by the authors. 
Financial Disclosure: The authors declared that this study has received no financial support.

\section{References}

1. Whiteford MH, Kilkenny J 3rd, Hyman N, Buie WD, Cohen J, Orsay C, Dunn G, Perry WB, Ellis CN, Rakinic J, Gregorcyk S, Shellito P, Nelson R, Tjandra JJ, Newstead G; Standards Practice Task Force; American Society of Colon and Rectal Surgeons. Practice parameters for the treatment of perianal abscess and fistula-in-ano (revised). Dis Colon Rectum 2005; 48:1337-1342.

2. Srivastava KN, Agarwal A. A complex fistula-in-ano presenting as a soft tissue tumor. Int J Surg Case Rep 2014;5:298-301.

3. Parks AG, Gordon PH, Hardcastle JD. A classification of fistula-in-ano. Br J Surg Jan 1976;63:1-12.

4. Schwartz's Principles of Surgery (2014) 10th edition by F. Brunicardi, McGraw-Hill Professional p-1230.
5. Chen C-W, Wu C-C, Hsiao C-W, Wang S-J, Jao S-W. Septic arthritis of hip jointsecondary to an anal fistula. J Med Sci 2008;28:151-q-154.

6. Bleier JI, Moloo H, Goldberg SM. Ligation of the intersphincteric fistula tract: an effective new technique for complex fistulas. Dis Colon Rectum 2010;53:43

7. Tan KK, Tan IJ, Lim FS, Koh DC, Tsang CB.The anatomy of failures following the ligation of intersphincteric tract technique for anal fistula: a review of 93 patients over 4 years. Dis Colon Rectum 2011;1354:13681372.

8. Attaallah W, Tuney D, Gulluoglu BM, Ugurlu MU, Gunal O, Yegen C. Should we consider topical silver nitrate irrigation as a definitive nonsurgical treatment for perianal fistula? Dis Colon Rectum 2014;57:882-887.

9. Ommer A, Herold A, Berg E, Fürst A, Sailer M, Schiedeck T; German Society for General and Visceral Surgery. Cryptoglandular anal fistulas. Dtsch Arztebl Int 2011;108:707-713.

10. van Koperen PJ, ten Kate FJ, Bemelman WA, Slors JF. Histological identification of epithelium in perianal fistulae: a prospective study. Colorectal Dis 2010;12:891-895. 